\title{
A Case Analysis of Business English Teacher Development in China with GDUFS as an Example
}

\author{
Zhu Wenzhong ${ }^{1} \&$ Deng Jingzi ${ }^{2}$ \\ ${ }^{1}$ School of Business and School of English for International Business, Guangdong University of Foreign Studies, \\ Guangzhou, China \\ ${ }^{2}$ School of English for International Business, Guangdong University of Foreign Studies, Guangzhou, China \\ Correspondence: Zhu Wenzhong, School of Business and School of English for International Business, \\ Guangdong University of Foreign Studies, Guangzhou 510420, China. E-mail: wenzhong8988@sina.com
}

Received: March 6, 2015 Accepted: April 7, 2015 Online Published: May 28, 2015

doi:10.5539/elt.v8n6p159 URL: http://dx.doi.org/10.5539/elt.v8n6p159

\begin{abstract}
Business English education has evolved into a cross-disciplinary programme in China as one of the hottest majors pursued by students and professionals. As Business English teaching develops in terms of diversity, richness, and depth, the demands placed on the teacher are also increasing. The paper assumes that the kind of teachers with multi-skills of both English language and business knowledge are the best to meet the requirement of Business English teaching. It makes a case analysis of the practice of Business English teacher development in China by taking Guangdong University of Foreign Studies (GDUFS) as an example, which mainly reflects into the types of teachers teaching Business English courses, the expectations of learners for Business English teachers, and the ways of Business English teacher development, etc. It summarizes the triple types of Business English teachers and the five approaches of Business English teacher development. On this basis, it proposes some implications for the trend of growing professionalism of Business English teachers.
\end{abstract}

Keywords: Business English; teacher development; GDUFS; case analysis

\section{Introduction}

Business English was officially approved by the Ministry of Education as a cross-disciplinary programme in China in 2007, and since then, has become one of the most welcome degree programmes in the national entrance examination each year. Today in China there are over 1000 higher education institutions which are offering Business English degree programmes or direction courses at both undergraduate and postgraduate levels, or Business English training courses for professionals. Up to now, there are 215 Chinese universities which have been officially approved to offer bachelor degree programmes of Business English major, and two universities including Guangdong University of Foreign Studies and University of International Business and economics are offering doctor degree programmes of Business English major.

And graduates of Business English major are highly recognized by business employers, especially the international business-related employers like MNCs and foreign trade enterprises.

However, the lack of competent Business English teachers in higher education institutions has restricted the development of this discipline and the quality of educated talents. According to the survey results of Tan (2010), there are $69 \%$ of the investigated teachers in the questionnaire survey who agree that Business English teachers are in shortage in their universities, and there are $27 \%$ who even agree that there is a severe shortage of Business English teachers in their universities. Similarly, in the case university of GDUFS, there is also a lack of competent Business English teachers in the institution as a whole, because these teachers are now overburdened with their teaching of many different business-related programmes which need to be taught in English or bilingual languages in the whole university or even in other universities, such as international MBA programmes, international franchising education porgrammes, and innovation class programmes in addition to their teaching responsibilities for Business English degree programmes in School of English for International Business.

In fact, over 20 years ago, GDUFS took the lead in experimenting and launching Business English courses in the whole country, and was one of the first three Chinese universities officially approved with the offering of Business English undergraduate degree programme in 2007, and the postgraduate degree programme in 2008, as 
well as the doctor degree programme in 2012. Every year, GDUFS gives offers to over 500 undergraduate students of Business English major, and about 40-50 postgraduate students of Business English major. And the graduates of Business English have demonstrated nearly 100\% employment level each year, and they are highly appreciated or recognized by their employers as a result of their high proficiency of English language ability, good international business knowledge, and excellent cross-cultural communication skills.

The success of Business English education programmes, of course, relies on the development of competent Business English teachers. What is important is that, today, the training objective for Business English talents has quietly changed as a result of the change of contemporary business model from visible goods trade to invisible services trade and the globalization of modern economy (Ye, 2014), this also means that the development of Business English teachers should also keep in line with the transformation of the related model of talent cultivation, in order to satisfy the need of current social and economic development.

This paper will make a case analysis of the practice of Business English teacher development in China by taking Guangdong University of Foreign Studies as an example. As for the main research questions of the present paper, it will reflect into the types of teachers teaching Business English courses for pre-experience learners, the expectations of learners for Business English teachers, and the approaches of Business English teacher development, etc., so as to propose some implications for facing the trend of growing professionalism of Business English teachers.

\section{Review of the Related Researches}

Teachers are the key foundation for the success of a degree programme. With the development of Business English education or training, teaching staff becomes one of the key research areas in both the world and China. In the west, Ellis and Johnson $(1994,2002)$ in their book Teaching Business English argues that there is a trend of growing professionalism of Business English trainers, who may have different backgrounds and experiences to be qualified for Business English training, with some of them coming from the post of general TEFL teaching or some having a business background with real working experiences in companies; Donna (2000) makes a comprehensive introduction to Business English, and provides both a comprehensive introduction to Business English for teachers who are new to the field, as well as inspiration and guidance for those already involved in this area, and it also deals with a range of issues from needs analysis and course planning to testing and evaluation.

In China, the related researches on Business English teacher development are mainly focusing on the following areas: first, Zheng (2007) makes an analysis of the development of "dual-teachers" mechanism for Business English major, arguing that he introduction of professionals from business world may not form a kind of overall advantage for Business English teaching; Yan (2007) makes a research on how to construct the teaching team of Business English major at vocational education level; Jian, Ding, Yang, and Gao (2008) makes a questionnaire investigation on the qualities of Business English teachers in China, and concludes that Business English teachers should process the ability of language communication, and then the method of class teaching and the ability of class organization, as well as the mastering of business knowledge and the accumulation of professional experience; Tang (2010) makes a study on the domestic development of Business English teachers, and proposes a guarantee measure for the personal development of Business English teachers.

Guo, Li, and Fan (2011) makes a study on the status quo and mode of Business English teacher development in Chinese local higher education institutions, and designs a new model of teacher development like "disciplinary development + business skills + professional ethics"; Li (2011) makes a SWOT analysis of Business English teacher development, and puts forward the challenges for and countermeasures to the development of Business English teachers such as the transformation of traditional English teachers, the applicability and cross-discipline of Business English programmes, and the shortage of Business English teacher training; Yang (2011) conducts an empirical study on professional qualities of business English teachers in several universities and concludes that as for the career development of business English teachers, they expect more opportunities of training and improvement in business knowledge, Business English teaching method, and curriculum design. Wang and Zhang (2011) makes a research on the factors affecting the ability of teachers in the construction of Business English discipline, and concludes that Business English teachers need to have a unique collective combination of abilities, and thus a multi-skilled teaching team should be built in addition to the professional quality of individual teachers.

Li (2012) makes an analysis of the "master duplication mode" of Business English teacher development, and provides an integration model of teacher teaching, research and personal development, and the future challenges facing the development of Business English teacher development; Shen (2012) makes an analysis of the 
cultivation model for international Business English teachers, and proposes the model of cultivation which covers learning, supervision, practice, research and evaluation.

However, the above existing researches on some broad and general issues concerning the development of Business English teachers have not focused on the specific case study of Business English teacher development based on one exemplary university's practice. Thus, the present research based on the case of GDUFS which is among China's top three foreign languages universities may have some more practical significance for the development of Business English teachers in the current situation.

\section{Case Analysis}

In the following will be the case analysis of Business English teacher development with GDUFS as an example, from the three main aspects or research questions, which include: the types of teachers teaching Business English courses (Triple types), the expectations of learners for the teachers, and the ways of Business English teacher development (Five approaches), etc.

\subsection{Types of Teachers Teaching Business English Courses}

In GDUFS, a separate school of Business English named as School of English for International Business was established in 2001, with its initial teaching staff respectively coming from several faculties or schools, such as Faculty of English Language and Culture, School of International Trade and Economics, School of International Business Management, and School of Law. Thus, from the very beginning, this School is formed by different types of teachers of academic backgrounds, who can be divided into three main types of teachers participating the teaching of Business English courses, here also briefly called the triple types (See Figure 1).

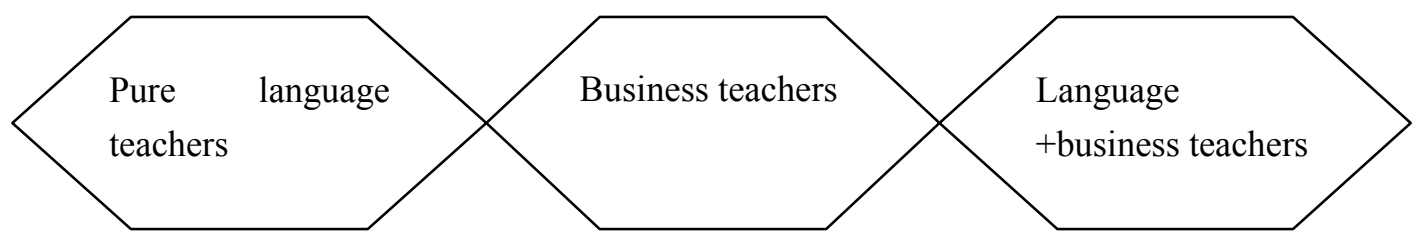

Figure 1. Triple types of Business English teachers in GDUFS

In GDUFS' School of English for International Business, there are approximately 100 teachers teaching Business English courses altogether, among whom pure English language teachers accounting for about $60 \%$ of the total are mainly responsible for teaching basic Business English language-related courses such as English Listening, speaking, reading and writing courses, etc., while business teachers and language + business teachers taking up about the remaining $40 \%$ are mainly responsible for the teaching of business knowledge-related courses.

In terms of qualifications and skills, pure English language teachers are those teachers who are graduates of English language major or English language master or doctor degree holders with language teaching abilities, but who may have no business professional experience or very limited business knowledge. However, business teachers are those teachers who are graduates of business-related majors like management, foreign trade, economics, finance, law, etc., or business-related master or doctor degree holders with English language teaching abilities, but who may or may not have business professional experiences.

In addition, language + business teachers are the kind of teachers who hold both English language-related master or doctor degree and business-related master or doctor degree certificates at the same time. This type of Business English teachers are increasing rapidly in the proportion as a result of the transformation of pure English language teachers. More and more such traditional English language teachers in the School, facing the challenge of teaching both English language and business professional skills in Business English courses, have completed or are studying for a master or doctor degree programme of business-related major, such as international business management, finance, economics, accounting, marketing, law, etc., whether in a domestic university or in an overseas university.

\subsection{Expectations of Learners for Business English Teachers}

Business English learners in GDUFS' School of English for International Business are actually the pre-experience learners who are college students passing the national entrance examination, although there may be some experienced learners from law firms, banks or other organizations who occasionally come to complete their short term off-the-job courses of Business English training. These students are very good students who are mostly among the top markings in the entrance examination. Graduates of this major, each year, demonstrate a 
very high employment rate and a very good job performance, as a result, sometimes, one third of these graduates are recruited by the world-famous Big 4 accounting firms like PricewaterhouseCoopers, Deloitte, international commercial banks or other multinational corporations like HSBC, CITI, etc. From the perspective of employment level and student career development ability, the Business English degree programme in GDUFS has been proven to be very successful. It is no doubt that the team of Business English teachers has played a very important role in the success of cultivating these students.

In recent years, our research team has shown an ongoing concern about the construction of Business English teaching team in GDUFS and has done some related empirical studies on the expectations of learners for their teachers. For, example, in 2010-2011, the author made a questionnaire investigation on this issue and reached the following findings concerning Business English students' expectations for their teachers' qualifications or abilities: namely, over $77 \%$ investigated students agree that it is the best for Business English teachers to hold both good English language proficiency and good business professional knowledge in a specialized field (Zhu, 2011). That is to say, most of the investigated students expect their Business English teachers to hold an English language-related master or doctor degree certificate and a business-related master or doctor degree certificate at the same time as education qualifications. No more than 6 percent of the students recognize the fact that their teachers only hold a single English language-related master or doctor degree certificate or a single business-related master or doctor degree certificate as education qualifications. In addition, there are also $11 \%$ of the students think that Business English teachers should better have some practical working experience in the real business world (See Figure 2). These findings indicate that in terms of teaching Business English courses, especially business-related courses, a majority of the students expect their teachers to have multi-skilled qualifications, namely they best like the "amphibious" type of Business English teachers who are good at both English language teaching and business professional knowledge.

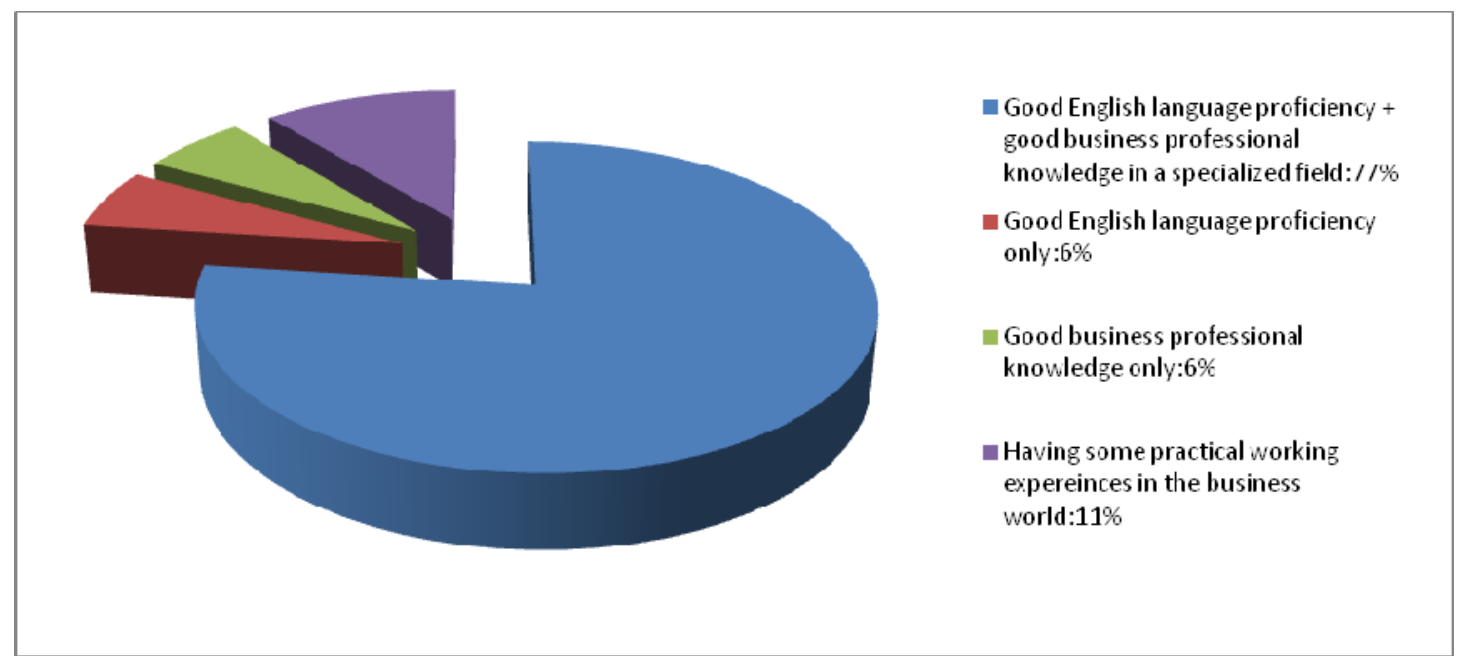

Figure 2. Questionnaire research findings of expectations of learners for their teachers in GDUFS

However, these findings are only the results purely based on the subjective expectation of the students at schooling. In the real teaching performance evaluation of GDUFS each semester, the most welcome teachers may not definitely be those teachers who hold both good English language proficiency and good business professional knowledge in a specialized field. On the contrary, quite a lot of teachers who hold a single English language-related master or doctor degree certificate or a single business-related master or doctor degree certificate as education qualifications are among the top recognized ones in the teaching performance evaluation.

In addition, A further investigation shows that the teachers of a single language-related degree qualification and those of a single business-related degree qualification should have a common advantage of good English proficiency in teaching Business English, which means that they are outstanding in English teaching, and they demonstrate very good English language proficiency. A Business English teacher of a single business-related degree qualification whose English language ability is not good enough is usually among the teachers who have a very low ranking order in the teaching performance evaluation each semester. This finding shows that Business English teachers should first become a competent English language teacher. 
In fact, it is commonly recognized that on the one hand, the teachers of a single language-related degree qualification in GDUFS have mostly received some kind of business knowledge-related trainings through attending training courses, attending business seminars, or conducting self-study of business theories or practices. On the other hand, the teachers with a single business-related degree qualification or without any English language-related degree education background are mostly very good in English language application and teaching, because some of these teachers have learned English very well in their schooling years as a kind of interest, although they are not students of English language major; some of these teachers may have long worked in a foreign corporation with English as daily communication language, or some may have studied, lived or worked in an English-speaking country for some years.

\subsection{Ways of Business English Teacher Development}

In GDUFS' School of English for International Business, a high-quality teaching team formed by over 100 Business English teachers has been gradually established as the commonly-accepted best teaching team in the whole nation through the "six approaches" of teacher development in the past decade. These teachers are highly welcome by the students of the School and also loved by the students of other faculties or schools like Graduate School of MBA, International School, and School of International Trade and Economics, where some of their innovative degree programmes are instructed in English or taught in bilingual languages. These approaches are illustrated as in Figure 3:

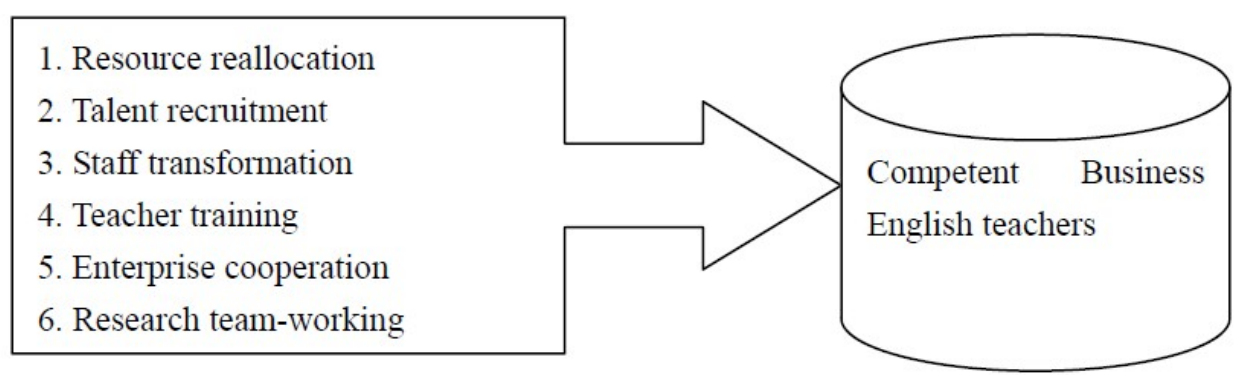

Figure 3. The "six approaches" of Business English teacher development

First, in terms of resource reallocation, when establishing School of English for International Business, GDUFS had reallocated its human resources of the whole university by inviting the teachers from several schools or faculties, who were able to teach Business English courses of the four directions of Business English major such as International Trade, International Finance, International Business Management and international Law, to join in the School, so that the three main types of teachers in the School were initially put into place for the teaching of Business English degree programmes. And these teachers today are still the main foundation in the School's overall teaching team, although some of them have retired or left.

Second, in terms of talent recruitment, GDUFS has implemented a staff plan to recruit the needed teachers step by step. In these years, more and more business professionals with English language proficiency are recruited into the teaching team to undertake the teaching task of business knowledge-related courses in English or bilingual languages, and at the same time, more and more doctor degree holders with pure language-related education background or business-related education background are also admitted or recruited into the teaching staff of the School. Of course, the newly recruited teachers with business-related education background are normally good or at least OK in English language proficiency and English teaching ability.

Third, in terms of staff transformation, GDUFS has encouraged its traditional pure English language teachers to transform themselves into more competent types of Business English teachers by the following ways, such as: some have chosen to study for a business-related doctor or master degree programme as a second degree in addition to their existing language-related degree programme; some have chosen to self study business knowledge by reading business books or attending business classes; some have chosen to study business knowledge by concerning, discussing and reflecting on the current hot topics of modern economic development and fiscal or monetary policies.

Forth, in terms of teacher training, GDUFS has conducted a series of training programmes for the development of Business English teachers. For example, each year, there are several teachers teaching Business English courses in English or bilingual languages who are selected and sent to study for a business-related degree 
programme or do researches as visiting scholars in foreign partnership universities with the sponsorship of the university's overseas study funds; there are also some training programmes for the teachers organized by the School, in which business teachers or business professionals are appointed to give a series of lectures for the English language teachers who want to improve their business skills or professional knowledge. In addition, seminars of Business English teaching and public criticism lessons of model teachers are organized by the School to create opportunities for the teachers to share ideas of how to improve Business English teaching quality.

Fifth, in terms of enterprise cooperation, GDUFS' School of English for International Business alone has signed a number of cooperative teaching and research bases with businesses, government authorities, and trade fair and exhibition organizations, and through the platform of enterprise cooperation, each year, the Business English teachers can conduct researches on authentic business management problems together with the experts or professionals in enterprises or invite the business professionals to come to the class to give lectures to the teachers and students of Business English major, so that the teachers can greatly improve their Business English teaching and research abilities by understanding the major issues in the real business world and combining the theory of business management in the textbook with the social practice.

Sixth, in terms of research team-working, in DGUFS' School of English for International Business, four research centers such as Research Center of Business English Teaching, Center of Forensic Studies, Center of Business Translation Studies, and Center of International Business Studies are established to conduct specific-issue researches by project-team-working, so that the team members can discuss, learn, and help each other in doing researches on issues of Business English teaching or specific fields of business management. The research findings done together by each project team have in turn enhanced the teaching and research performance of an individual Business English teacher as a member of the team.

\section{Conclusion and Implication}

To sum up, the existing researches chiefly on some broad and general issues concerning the development of Business English teachers have not focused on the specific case study of Business English teacher development based on one exemplary university's practice. The case study of GDUFS as one of the top universities in Business English teaching is of practical importance for references of other universities with similar degree programmes. The case research findings indicate that: in GDUFS, there exist triple types of teachers teaching Business English courses, who are 1) pure English language teachers accounting for about $60 \%$ of the total mainly responsible for teaching basic Business English language-related courses, 2) business teachers and 3) language + business teachers taking up approximately $40 \%$ mainly responsible for the teaching of business knowledge-related courses; a majority of investigated Business English students agree that it is the best for Business English teachers to hold both good English language proficiency and good business professional knowledge in a specialized field, namely they best like the "amphibious" type of Business English teachers who are good at both English language teaching and business professional knowledge; GDUFS has successfully followed the "six approaches" of teacher development in the past decade, which include resource reallocation, talent recruitment, staff transformation, teacher training, enterprise cooperation, and research team-working.

The case research brings at least the following implications to other Chinese universities or even foreign universities having similar Business English degree programmes: 1) Business English teachers with whether business-related degree education or English language-related degree qualifications should first become a competent English language teacher; 2) there is a need to develop the type of "language + business "multi-skilled teachers teaching Business English courses as these teachers are most expected by the students; 3) the professional development of Business English teachers requires the taking of a variety of approaches together in order to achieve the expected results.

\section{References}

Donna, S. (2000). Teach Business English: A Comprehensive Introduction to Business English. Cambridge University Press.

Ellis, M., \& Johnson, C. (1994). Teaching Business English. Cambridge University Press.

Ellis, M., \& Johnson, C. (2002). Teaching Business English. Shanghai Foreign Language Education Press.

Guo, N. Z., Li, C., \& Fan, Q. Z. (2011). Study on the status quo and mode of Business English teacher development in Chinese local higher education institutions. Theory and Practice of Education.

Jiang, C., Ding, C. W., Yang, J., \& Gao, H. S. (2008). Investigation report on the qualities of Business English teachers in China. Business English Teaching and Research. 
Li, M. Q. (2011). A SWOT analysis of Business English teacher development and countermeasures. Business English Teaching and Research.

Li, Y. X. (2012). An analysis of the "master duplication mode" of English teacher development with Business English teacher development as an Example. Foreign Language in China.

Shen, Y. (2012). An analysis of the cultivation model for international Business English teachers. China Adult Education.

Tan, Y. M. (2010). Strategies for BE Teachers' Professional Development. Zhejiang Gongshang University.

Tang, Y. L. (2010). Investigation and research on the domestic status and demand of Business English teacher development. Journal of Changchun Institute of Technology. Social Sciences Edition.

Wang, G. F., \& Zhang, H. S. (2011). Research on Ability Elements of Teachers in the Construction of Business English Discipline. Foreign Language World.

Yan, M. J. (2007). The construction of teaching team of Business English major at vocational education level. Mechanical Professional Education.

Yang, N. W. (2011). An Empirical Research on Professional Qualities of Business English Teachers. http://www.cnki.net/KCMS/detail/detail.aspx?QueryID=8\&CurRec=18\&recid=\& filename=101130275

Ye, X. G. (2014). The Origin of China's Business English Major Education, Status Quo and Development Trend. Contemporary Foreign Language Studies.

Zheng, S. Y. (2007). The issue of developing “dual-teachers” staff for Business English Major. Crazy English (Teachers).

Zhu, W. Z. (2011). Business English Teaching and Research. China Publishing Corporation.

\section{Copyrights}

Copyright for this article is retained by the author(s), with first publication rights granted to the journal.

This is an open-access article distributed under the terms and conditions of the Creative Commons Attribution license (http://creativecommons.org/licenses/by/3.0/). 